\title{
Assessment of Groundwater quality in Krishnagiri and Vellore Districts in Tamil Nadu, India
}

\author{
A. Shanmugasundharam ${ }^{1}$ - G. Kalpana ${ }^{1}$ - S. R. Mahapatra ${ }^{1}$ - E. R. Sudharson ${ }^{1}$ • \\ M. Jayaprakash ${ }^{1}$
}

Received: 16 April 2015/ Accepted: 26 October 2015/Published online: 20 November 2015

(c) The Author(s) 2015. This article is published with open access at Springerlink.com

\begin{abstract}
Groundwater quality is important as it is the main factor determining its suitability for drinking, domestic, agricultural and industrial purposes. The suitability of groundwater for drinking and irrigation has been assessed in north and eastern part of Krishnagiri district, South-western part of Vellore district and contiguous with Andhra Pradesh states, India. A total of 31 groundwater samples were collected in the study area. The groundwater quality assessment has been carried out by evaluating the physicochemical parameters such as $\mathrm{pH}, \mathrm{EC}, \mathrm{TDS}, \mathrm{HCO}_{3}^{-}, \mathrm{Cl}^{-}, \mathrm{SO}_{4}^{2-}, \mathrm{Ca}^{2+}$, $\mathrm{Mg}^{2+}, \mathrm{Na}^{+}$and $\mathrm{K}^{+}$. The dominant cations are in the order of $\mathrm{Na}^{+}>\mathrm{K}^{+}>\mathrm{Ca}^{2+}>\mathrm{Mg}^{2+}$ while the dominant anions have the trends of $\mathrm{Cl}^{-}>\mathrm{HCO}_{3}^{-}>\mathrm{SO}_{4}^{2-}>\mathrm{CO}_{3}$. The quality of the water is evaluated using Wilcox diagram and the results reveals that most of the samples are found to be suitable for irrigation. Based on these parameters, groundwater has been assessed in favor of its suitability for drinking and irrigation purpose.
\end{abstract}

Keywords Groundwater · Major ions · Quality assessment

\section{Introduction}

Groundwater, being the largest freshwater resource after glaciers and polar ice in the world, plays an important role in socio-economic life of the people in Tamil Nadu for domestic,

M. Jayaprakash

emjaypee@gmail.com

1 Department of Applied Geology, Global and Environmental Change Research Group, University of Madras, Guindy Campus, Tamil Nadu, India horticultural, agricultural, and hydropower generation purposes. The suitability of groundwater for different purposes depends upon its intrinsic quality which reflects inputs from the atmosphere, soil and rock weathering, as well as from anthropogenic activities. Public ignorance of environment and related considerations, indiscriminate disposal of increasing anthropogenic wastes, unplanned application of agrochemicals, and discharges of improperly treated sewage have resulted in the deterioration of surface and subsurface water (Singh and Hasnain 1998; Mitra et al. 2007; Kumar et al. 2008; Ishaku 2011; Ewusi et al. 2013; Kalpana and Elango 2013). The value of groundwater lies not only in its widespread occurrence and availability but also in its consistent good quality (Rajmohan et al. 2000; UNESCO 2000).

It has been estimated that once pollution enters the subsurface environment, it may remain concealed for many years, becoming dispersed over wide areas of groundwater aquifer and rendering groundwater supplies unsuitable for consumption and other uses (Nagarajan et al. 2010). Water chemistry differs depending on the source of water, the degree to which it has been evaporated, the types of rock and mineral it has encountered, and the time it has been in contact with reactive minerals (Plummer et al. 2003; Arshid et al. 2011). Assessment of water quality is very important for knowing the suitability for various purposes (Ifatimehin and Musa 2008; Arshid et al. 2011).

The urban aquifers are the only natural resource for drinking water supply, they are often perceived as of lesser relevance for the drinking water supply, leading to crisis in terms of drinking water scarcity, becoming increasingly polluted thereby decreasing their potability (Tiwari et al. 2012). The knowledge of hydro-chemistry is important to assess the ground water quality in any area in which the ground water is used for both irrigation and drinking needs (Srinivas et al. 2013). The water quality assessment may

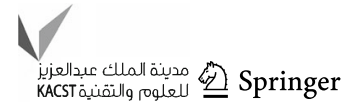


Table 1 Comparison of analytical results with international and national standards

\begin{tabular}{|c|c|c|c|c|c|}
\hline Parameter & Max & Min & Mean & $\begin{array}{l}\text { WHO Guideline } \\
\text { Value (2004) }\end{array}$ & $\begin{array}{l}\text { BIS Standards } \\
(2000)\end{array}$ \\
\hline $\mathrm{EC}(\mu \mathrm{S} / \mathrm{cm})$ & 2306.25 & 471.5 & 927.0 & 1500 & - \\
\hline $\mathrm{pH}$ & 8.4 & 7.4 & 7.9 & $6.5-8.5$ & $6.5-8.5$ \\
\hline TDS (mg/l) & 1476 & 301.8 & 593.3 & 1500 & $500-2000$ \\
\hline $\mathrm{Ca}(\mathrm{mg} / \mathrm{l})$ & 54 & 10.0 & 21.8 & 200 & $75-200$ \\
\hline $\mathrm{Mg}(\mathrm{mg} / \mathrm{l})$ & 42 & 3.6 & 26.9 & 150 & - \\
\hline $\mathrm{Na}(\mathrm{mg} / \mathrm{l})$ & 558 & 67.0 & 156.7 & 200 & $200-400$ \\
\hline $\mathrm{K}(\mathrm{mg} / \mathrm{l})$ & 103 & 2.0 & 20.2 & 12 & - \\
\hline $\mathrm{CO}_{3}(\mathrm{mg} / \mathrm{l})$ & 15 & 0.0 & 2.5 & - & - \\
\hline $\mathrm{HCO}_{3}(\mathrm{mg} / \mathrm{l})$ & 94 & 30.5 & 69.3 & 500 & - \\
\hline $\mathrm{Cl}(\mathrm{mg} / \mathrm{l})$ & 710 & 96.0 & 254.2 & 600 & 250 \\
\hline $\mathrm{SO}_{4}(\mathrm{mg} / \mathrm{l})$ & 59 & 35.3 & 42.2 & 250 & $200-400$ \\
\hline
\end{tabular}

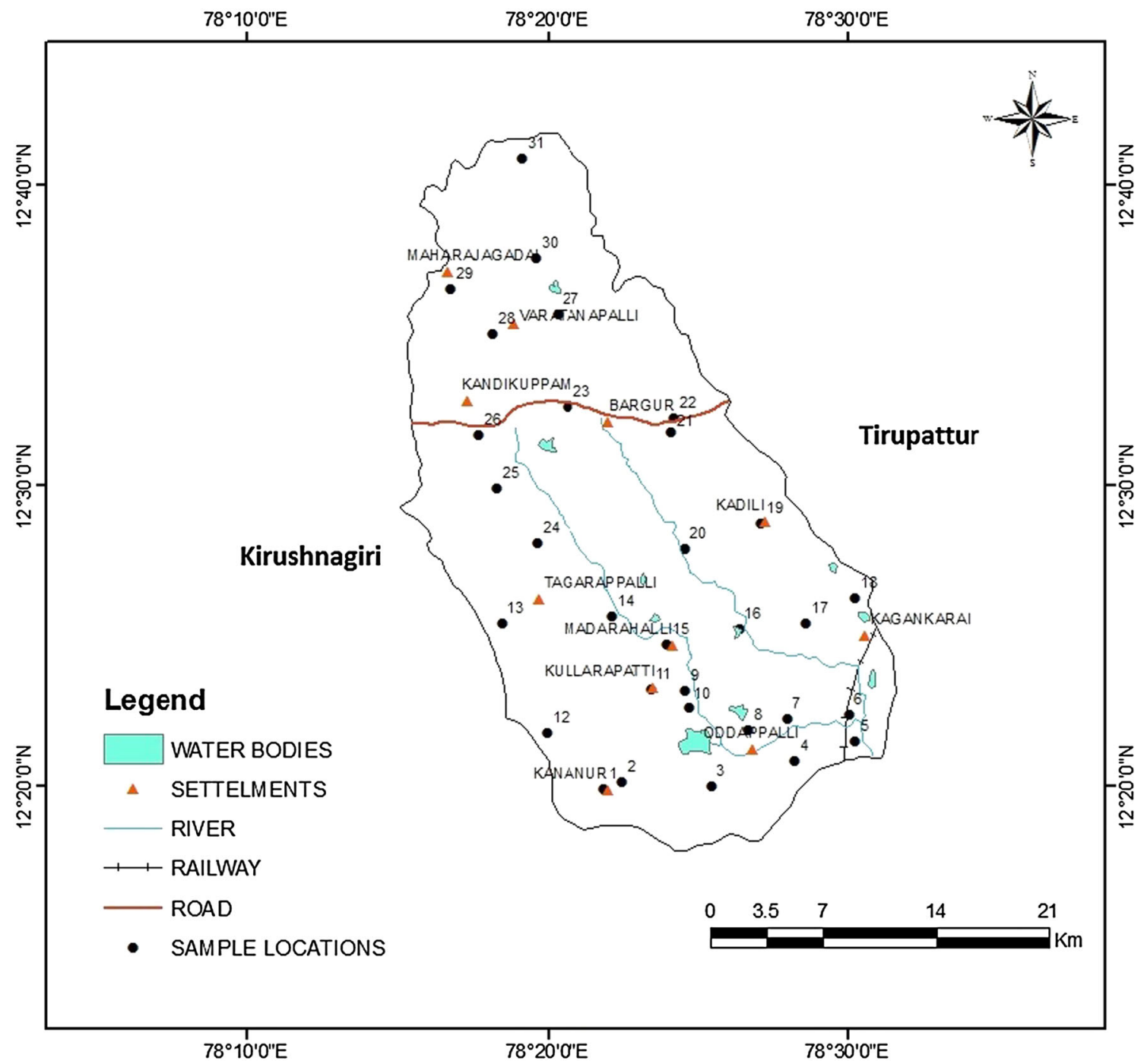

Fig. 1 Study area map 
give clear information about the subsurface geologic environments in which the water presents (Raju et al. 2011)

Most studies on water quality have been carried out by various researchers in many places in India (Raju et al. 2011; Srinivasamoorthy et al. 2011; Subramanian 2011; Gnanachandrasamy et al. 2013; Annapoorna and Janardhanab 2015; Nagaraju et al. 2014; Sajil Kumar et al. 2013). Hydrogeochemical investigation of groundwater has been carried out in the coastal aquifers of southern Tamil Nadu, India (Chandrasekar et al. 2014). Ashwani and Abhay (2014) have studied groundwater chemistry of Pratapgarh district in Uttar Pradesh.

Since water is a precious natural resource, for sustaining all life on the earth and due to its multiple benefits and the problems created by its excesses, shortage and quality deterioration, water as a resource requires special attention. So the aim of the study is to assess the quality of groundwater and to assess the spatial distribution of various hydrogeochemical parameters for suitability of groundwater resources in the study area as it is densely populated area and they mostly demand on the groundwater resources.

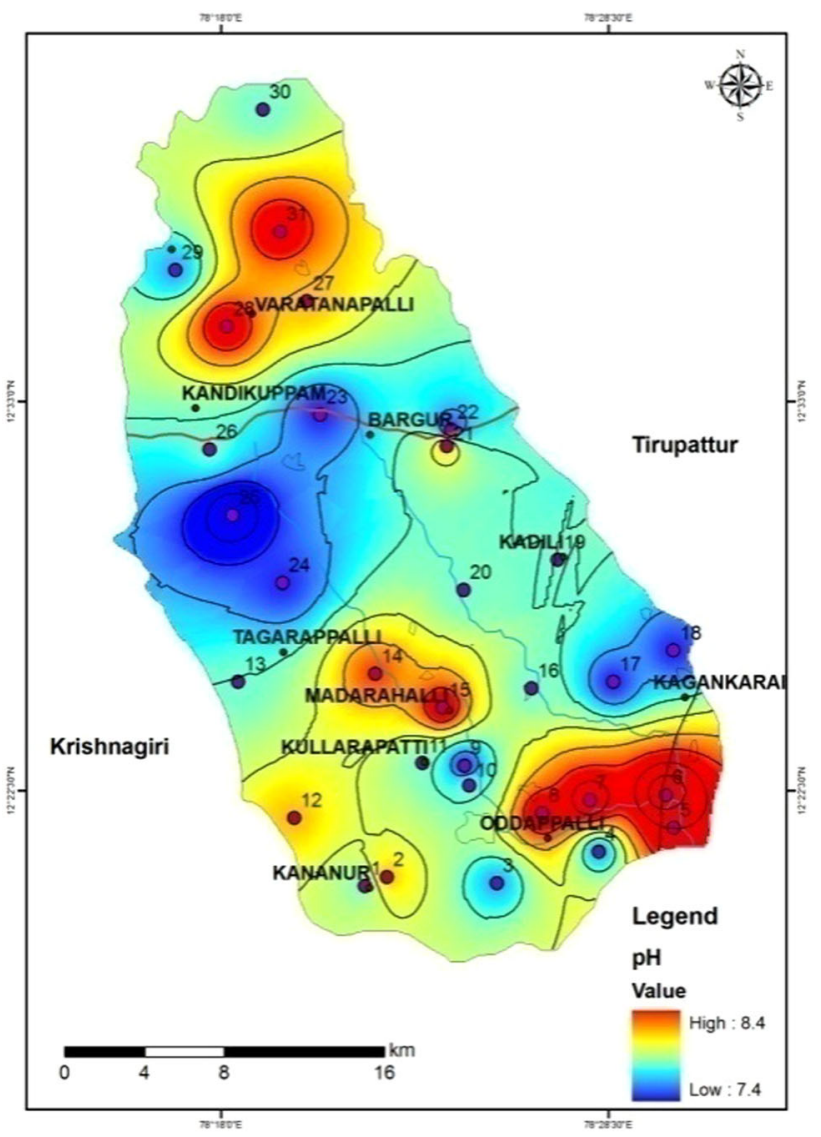

Fig. 2 Spatial variation of distribution of $\mathrm{pH}$ in study area

\section{Study area}

The study area is located in the northern part of Tamil Nadu State in India and is situated between north eastern part of Krishnagiri district and south western part of Vellore district. It lies between latitudes $12^{\circ} 17^{\prime} 40^{\prime \prime}$ and $12^{\circ} 41^{\prime} 53^{\prime \prime}$ and longitudes $78^{\circ} 14^{\prime} 56^{\prime \prime}$ and $78^{\circ} 31^{\prime} 38^{\prime \prime}$ (Fig. 1). The study area is drained by Bargur and Mathur rivers. These two rivers merge at the southeast corner, where the Pambar River originates and finally joins the river Ponnaiyar. The study area covers an area of $781 \mathrm{sq} . \mathrm{km}$ in the Survey of India toposheet numbers $57 \mathrm{~L} / 6$, $57 \mathrm{~L} / 7$ and $57 \mathrm{~L} / 11$ on a scale of 1:50,000. Topography of the area is highly and full of massive rock shoots with fracture zone. A wide array of litho unit ranging from alkali syenites and ultramafics complexes and younger dolerite like intrusive are exposed in the study area. Also, an intrusive igneous complex of Proterozoic age, younger dykes and recent alluvial cover along the Bargur and Mattur river course cover up rest of the geology. The area has a sub-tropical climate without any sharp variations. Temperatures vary from $40{ }^{\circ} \mathrm{C}$ in summer to around $20^{\circ} \mathrm{C}$ in the winter season. The average rainfall is 857 mm/year. Public Work Department Report (2004).

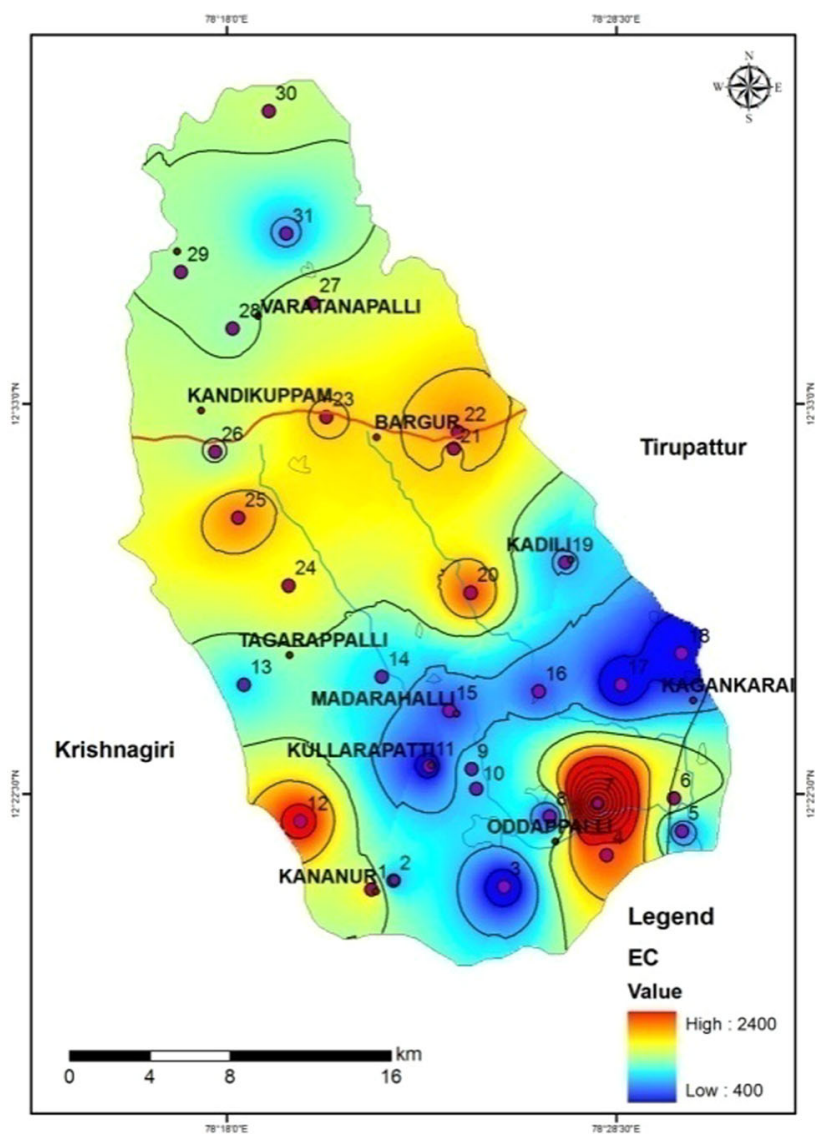

Fig. 3 Spatial variation of distribution of EC in study area 
In the present research work, the study area consists of part of two districts namely, Vellore and Krishnagiri. Both the districts have large industrials profiles such as textiles, leather tanneries and small-scale dying industries. The effluents of the leather industries, usage of the chemical fertilizers for agriculture and small-scale dying industries fall heavily on the quality of the drinking water. The impact is felt very much on the drinking water sources which are available for the people, settled on the banks of the river. (Dhiviyaa Pranavam et al. 2011).

\section{Hydrogeology}

Weathered and fractured Archaean crystalline rocks construct the major aquifer systems in the study area. The thickness of weathered zones ranges from less than a meter to more than $15 \mathrm{~m}$. Generally, the groundwater occurs under phreatic conditions in the weathered mantle and under semi-confined conditions in the fractured zones at deeper levels. The occurrence and movement of ground water are controlled by various factors such as physiography, climate, geology and structural features (CGWBoard 2009).

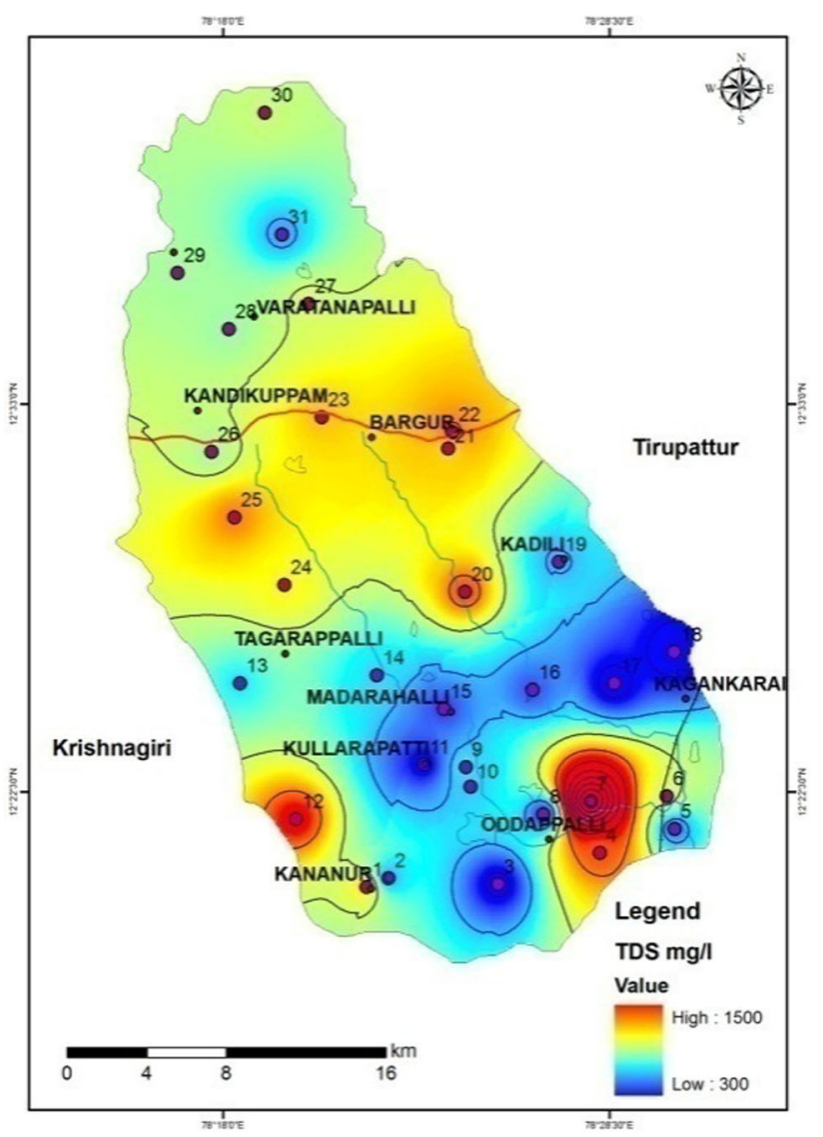

Fig. 4 Spatial variation of distribution of TDS in study area

\section{Methodology}

The Groundwater samples were collected from 31 well locations which fall in 28 mini watersheds in both Krishnagiri and Vellore districts. Among the 31 well locations, most of the wells are situated near or surroundings of Bargur and Mattur river, which are the mini tributaries Ponnaiyar river. The water samples were collected in definite intervals in a grid pattern. The samples were stored in plastic bottles, which pre-cleaned with $1 \mathrm{~N}$ hydrochloric acid and rinsed 3-4 times with distilled water. Water analysis was done using standard methods for the examinations of water and waste water (APHA 1999). EC and pH were measured in the field using calibrated thermometer with a resolution of 0.1 and Elico portable water quality analyser, respectively. Total dissolved solids (TDS) were computed by multiplying the electrical conductivity (EC) by a factor (0.64). Total hardness (TH) as $\mathrm{CaCO}_{3}$ and calcium $(\mathrm{Ca})$ were analyzed titrimetrically, using standard EDTA. Magnesium (Mg) was calculated by taking the differential value between total hardness $(\mathrm{TH})$ and calcium $(\mathrm{Ca})$ concentrations. Chloride (Cl)) was determined titrimetrically by standard $\mathrm{AgNO}_{3}$ titration. The content of sodium $(\mathrm{Na})$ and potassium $(\mathrm{K})$ in

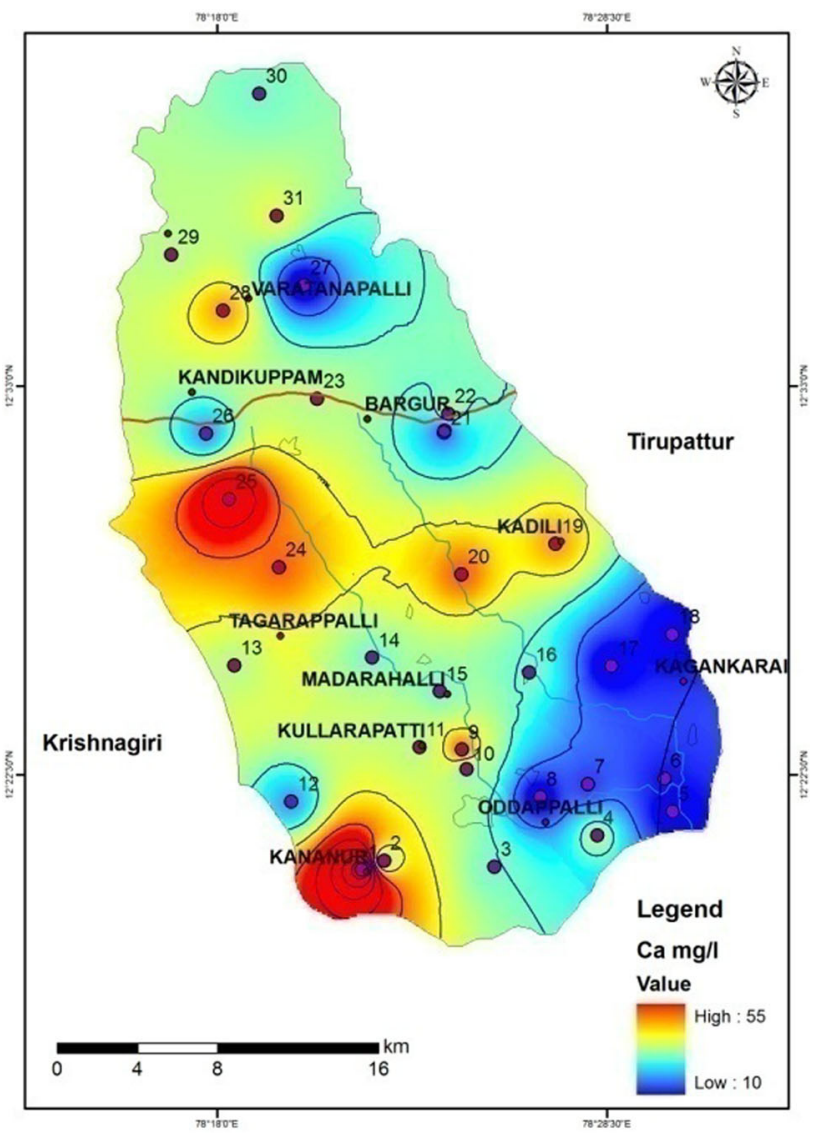

Fig. 5 Spatial variation of distribution of $\mathrm{Ca}$ in study area 
groundwater was estimated using EEL flame photometer with proper Air-LPG flame, sodium and potassium sulfate standards of appropriate concentrations were used.

All parameters are expressed in milligrams per liter (mg/ 1), except $\mathrm{pH}$ (no units) and electrical conductivity (EC). The electrical conductivity (EC) is expressed in microsiemens $/ \mathrm{cm}(\mu \mathrm{S} / \mathrm{cm})$ at $25{ }^{\circ} \mathrm{C}$.

\section{Result and discussion}

The various physicochemical parameters of groundwater samples were analyzed and the descriptive statistics of the analyzed parameters are given in Table 1. The results are compared to the World Health Organization recommended maximum permissible limits and BIS standards.

The data in Table 1 showed that $\mathrm{pH}$ of the groundwater ranged from 7.4 to 8.4 and average value is 7.9 indicating slight alkalinity. The lowest $\mathrm{pH}$ (7.4) was found in the station 25 and the highest $\mathrm{pH}$ (8.4) was found in the sample station 6 . Spatial distribution of $\mathrm{pH}$

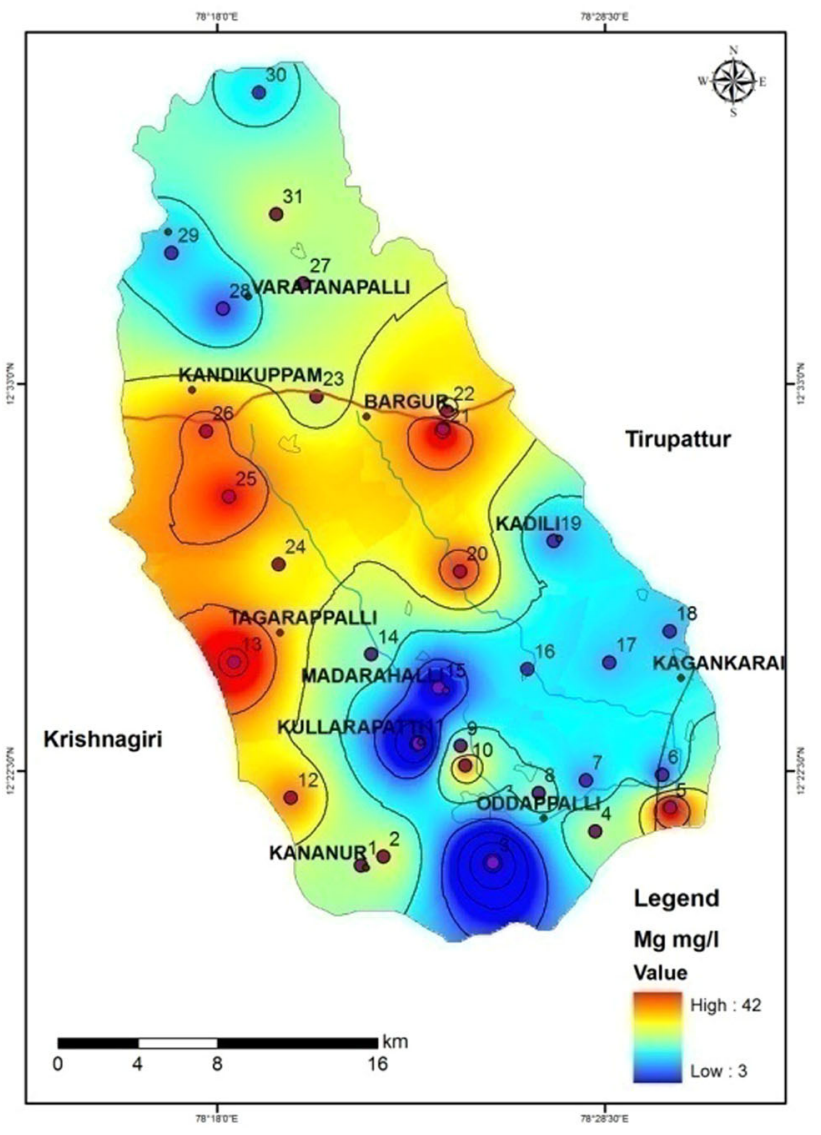

Fig. 6 Spatial variation of distribution of $\mathrm{Mg}$ in study area is shown in Fig. 2. The permissible range of $\mathrm{pH}$ for drinking and agricultural purposes is 6.5-8.5 (IS: 10500-1991). Most of the samples fall in within the permissible range.

The electrical conductivity in groundwater ranged from 471.5 to $2306 \mu \mathrm{S} / \mathrm{cm}$ and the mean value is $927 \mu \mathrm{S} / \mathrm{cm}$. The higher EC values show at station 7. Figure 3 shows the spatial distribution of EC values and that is increasing north to south. It is indicating the flow direction. The large variations in EC are mainly attributed to anthropogenic activities and to geochemical processes prevailing in this region. EC generally increases along a groundwater flow path because of the combined effects of evaporation, ionexchange, and topographic conditions (Toth 1999). The spatial distribution diagram (Fig. 4) of TDS also showing similar type variation like $\mathrm{EC}$, and the values range from 301 to $1476 \mathrm{mg} / \mathrm{l}$ and mean $593 \mathrm{mg} / \mathrm{l}$ the TDS concentration basically depends on what are the ions present in water. The calcium and magnesium in waters are generally used to classify the suitability of water. Calcium and magnesium are directly related to hardness of the water and these ions are the most abundant elements in the

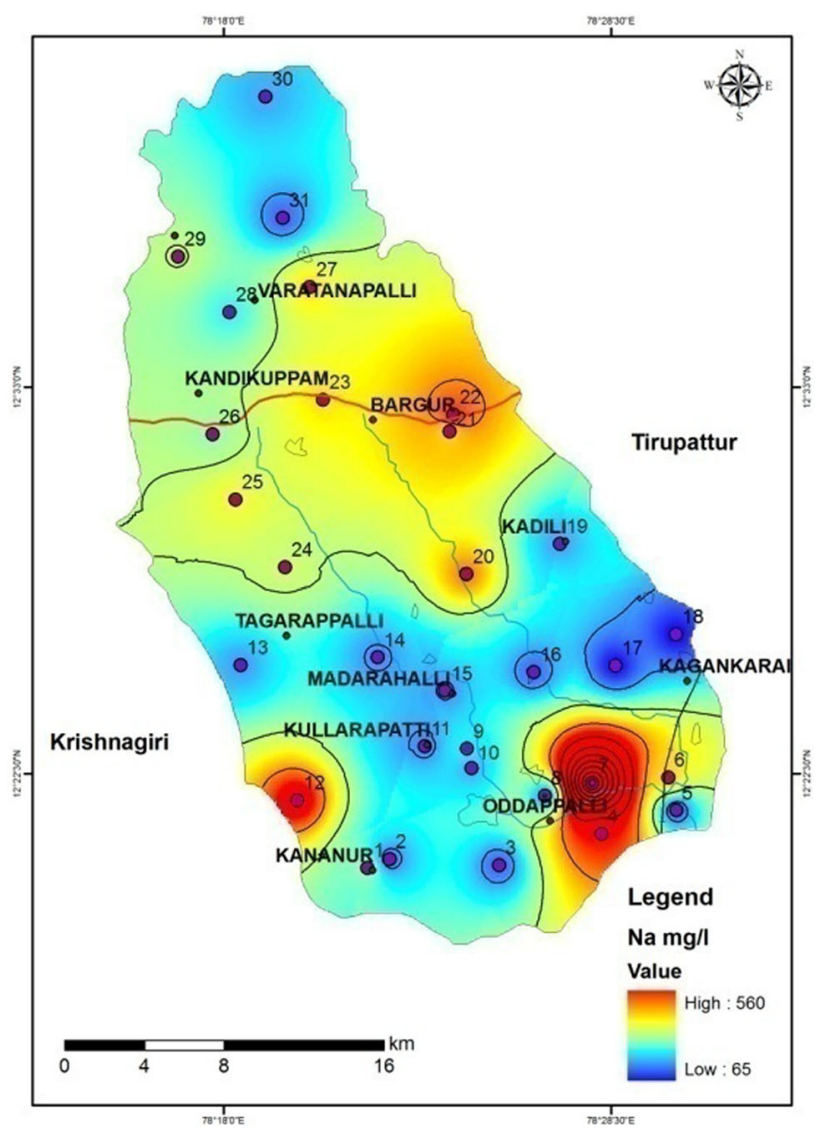

Fig. 7 Spatial variation of distribution of $\mathrm{Na}$ in study area

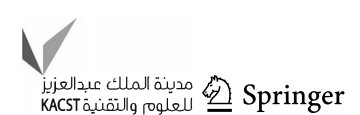


surface and groundwater and exist mainly as bicarbonates and to a lesser degree in the form of sulfate and chloride (Krishna Kumar et al. 2014). Calcium in the study area varied from 10 to $54 \mathrm{mg} / \mathrm{l}$. Mg varies from 3.6 to $42 \mathrm{mg} / \mathrm{l}$. $\mathrm{Ca}$ and $\mathrm{Mg}$ concentrations are within the permissible limits. The order of abundance of cations is $\mathrm{Na}^{+}>-$ $\mathrm{K}^{+}>\mathrm{Ca}^{2+}>\mathrm{Mg}^{2+}$. Higher concentration of $\mathrm{Na}$ observed in station 7 may be due to contribution from silicate weathering process and agricultural sources. $\mathrm{K}$ is higher due to weathering of feldspar and clay minerals from the surrounding substance to the aquifer. The anion chemistry shows that $\mathrm{Cl}^{-}$and $\mathrm{HCO}_{3}^{-}$are the dominant anions followed by $\mathrm{SO}_{4}^{2-}$, and $\mathrm{CO}_{3}^{-}$(Table 1). The chloride ion is the most predominant natural form of the element chlorine and is extremely stable in water. The chloride in groundwater may be from diverse sources such as weathering, leaching of sedimentary rocks and soil, domestic and municipal effluents (Sarath Prasanth et al. 2012). Cl was higher due to leaching from upper soil layers derived from industrial and domestic activities and dry climates (Srinivasamoorthy et al. 2008). The higher concentration of $\mathrm{HCO}_{3}$ was may be due to the effect dissolution of silicates and rock weathering. Higher

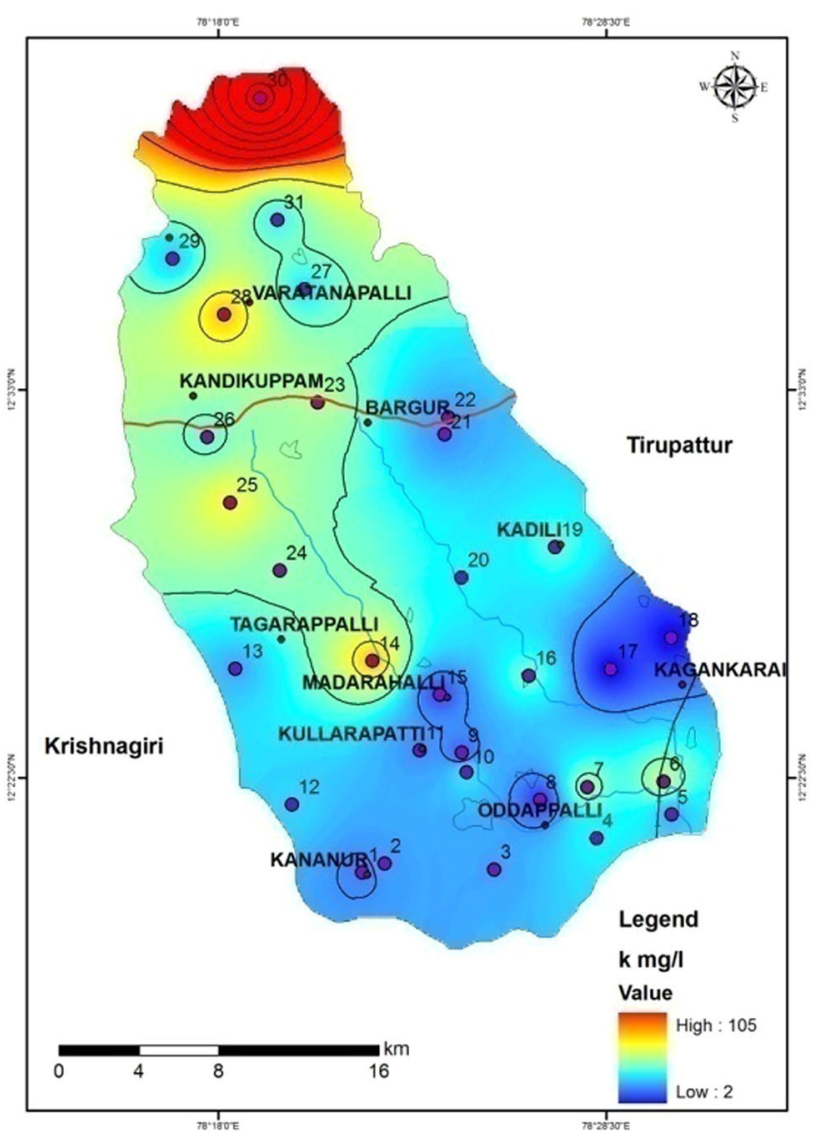

Fig. 8 Spatial variation of distribution of $K$ in study area concentration of chloride in water is often found in conjunction with higher sodium concentration. ICMR and BIS have prescribed $250 \mathrm{mg} / \mathrm{l}$ as the maximum permissible value. If the chlorine value exceeds $300 \mathrm{mg} / \mathrm{l}$ and the presence of a major cation is sodium, then the water becomes salty and similar observation is seen in the present study area (Ravisankar and Poongothai 2008). The spatial distribution of all the anions and cations is shown in the Figs. 5, 6, 7, 8, 9, 10, 11, 12. The spatial distributions of major ions of groundwater samples are clearly showing the flow of ground water northwest to southeast direction.

\section{Hydrochemical facies}

The conventional techniques such as trilinear plots, statistical techniques are widely accepted methods to evaluate water quality for various uses. The problems of groundwater quality are more acute in areas that are coastal, densely populated and thickly industrialized and have shallow groundwater tube wells (Krishna Kumar et al. 2011; Padmalal et al. 2012; Bagyaraj et al. 2013; Selvam et al. 2013). The chemical processes and the evolution of

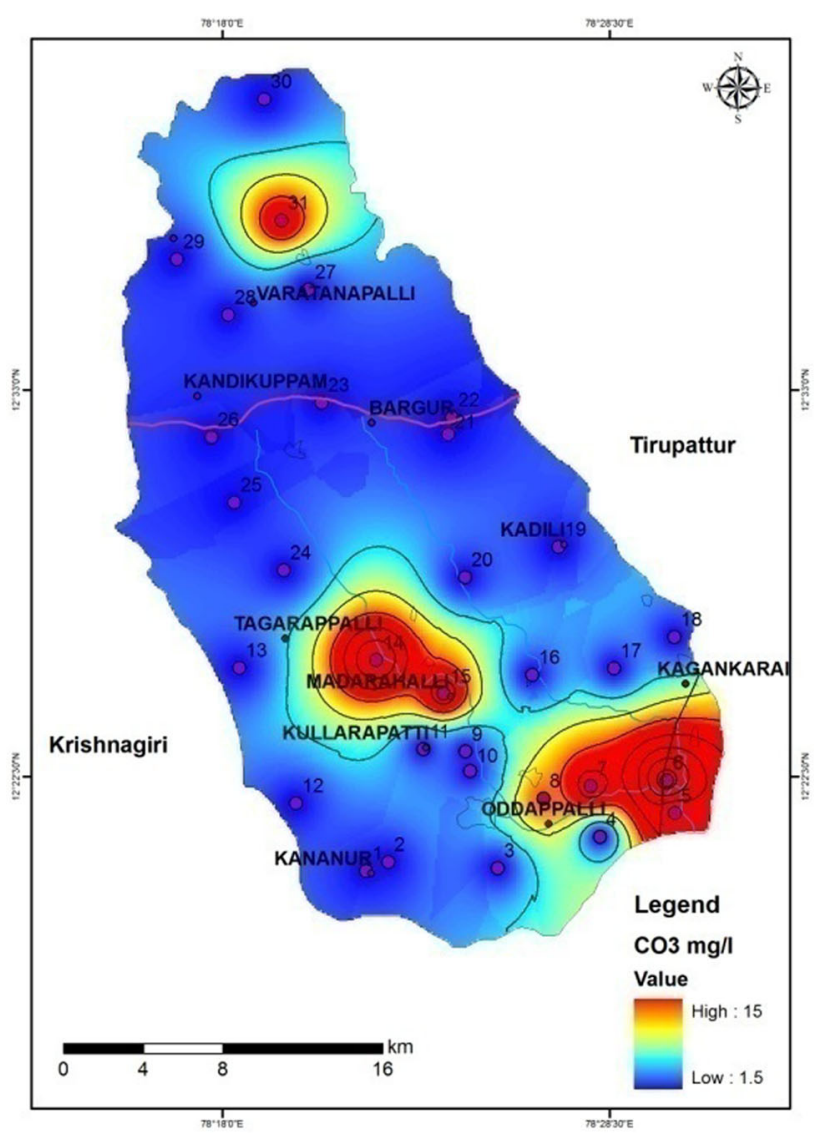

Fig. 9 Spatial variation of distribution of $\mathrm{CO}_{3}$ in study area 
the groundwater in the aquifers due to the residence and the flow may be evaluated using the hydrochemical facies. This can be well interpreted by drawing the Piper diagram (Piper 1953). The elevation of hydrochemical parameters of ground water can be understood by plotting the concentration of major cations and anions in the piper diagram (Fig. 13). The plots show that most of the water falls in the field of $\mathrm{NaCl}$ with one stations showing mixed $\mathrm{CaMgCl}$. From the plot, it is observed that alkalis ( $\mathrm{Na}$ and $\mathrm{K}$ ) exceed the alkaline earth ( $\mathrm{Ca}$ and $\mathrm{Mg}$ ) and $\mathrm{Cl}$ exceeds other anions.

\section{Wilcox diagram}

According to the sodium $\%$ and specific conductance in evaluating the suitability of the water samples are varying from excellent to doubtful classes for irrigation. The results show that (Fig. 14) about $52 \%$ of the samples fall in the very good to good region; $6 \%$ samples are in the good to permissible region indicating that these waters are very much suitable for irrigation. $32 \%$ of the samples fall in the permissible to doubtful region and only one sample fall in the doubtful to unsuitable region (Table 2). This station demonstrates high TDS value with higher concentration of Na. Since excess sodium affects the plants, the water

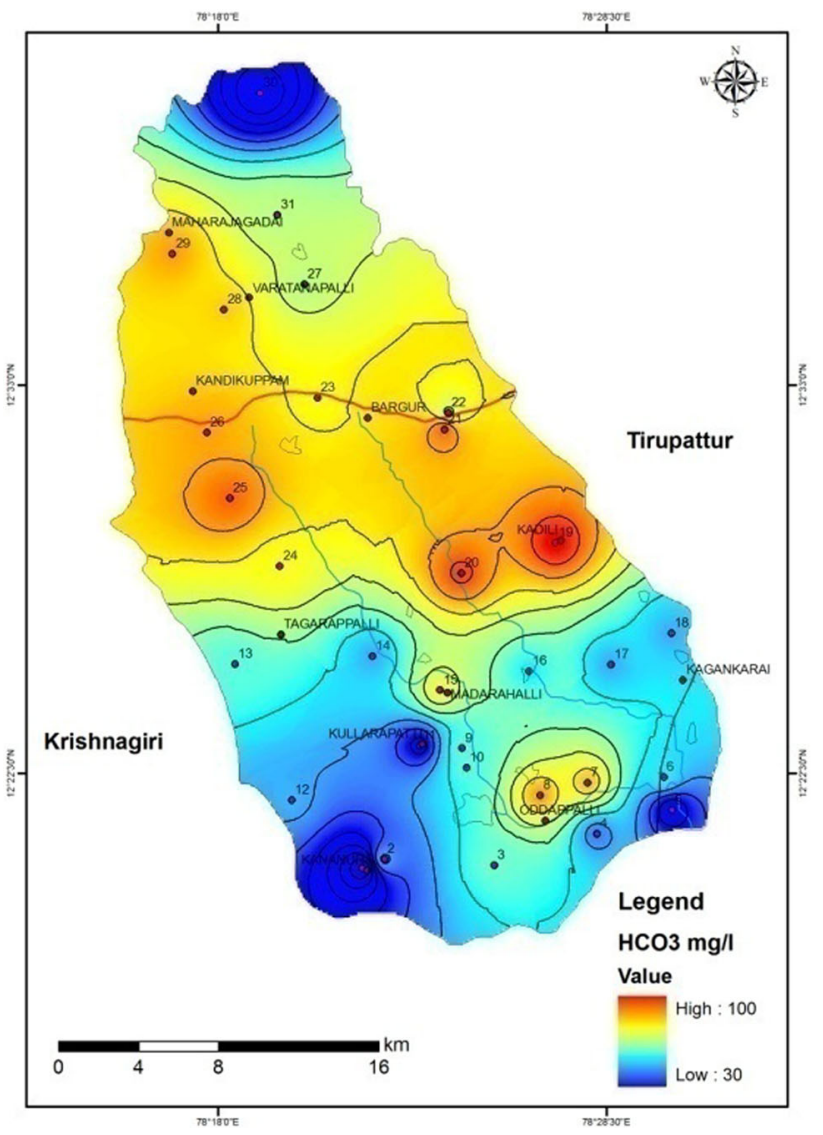

Fig. 10 Spatial variation of distribution of $\mathrm{HCO}_{3}$ in study area belongs to this station (Station 7) and is not suitable for irrigation.

\section{Statistical analysis}

The correlation coefficient is commonly used to measure the relationship between two variables. It is a measure to exhibit how well one variable predicts the behavior of the other (Lee et al. 2003). The results show that (Table 2) the $\mathrm{Na}$ has highly significant correlation with $\mathrm{Cl}$ and $\mathrm{SO}_{4}$. Similarly, $\mathrm{Mg}$ and $\mathrm{K}$ have positive correlation with $\mathrm{Cl}$. The hydrochemical character of alkalies explains the correlation of sodium with chlorine ion. $\mathrm{CO}_{3}$ showing high significant correlation with $\mathrm{pH}$, indicating that changes in the hydrogen ion concentration will directly correlation of carbonate in the water. The $\mathrm{Ca} / \mathrm{Na}$ ratio is estimated to be 0.14 which is slightly below the value deduced by Galy and France-Lanord (1999). Among the cations, no significant correlation is observed highly competitive relationship but in the case of anions $\mathrm{Cl}$ has significant correlation with $\mathrm{SO}_{4} . \mathrm{HCO}_{3}$ and $\mathrm{CO}_{3}$ have low positive correlation with $\mathrm{SO}_{4}$, low correlation exists between $\mathrm{K}$ and $\mathrm{Cl}$; $\mathrm{Na}$ and $\mathrm{CO}_{3} . \mathrm{Cl}$ is the dominant ion in anions, and its higher concentration is observed along the course of the river,

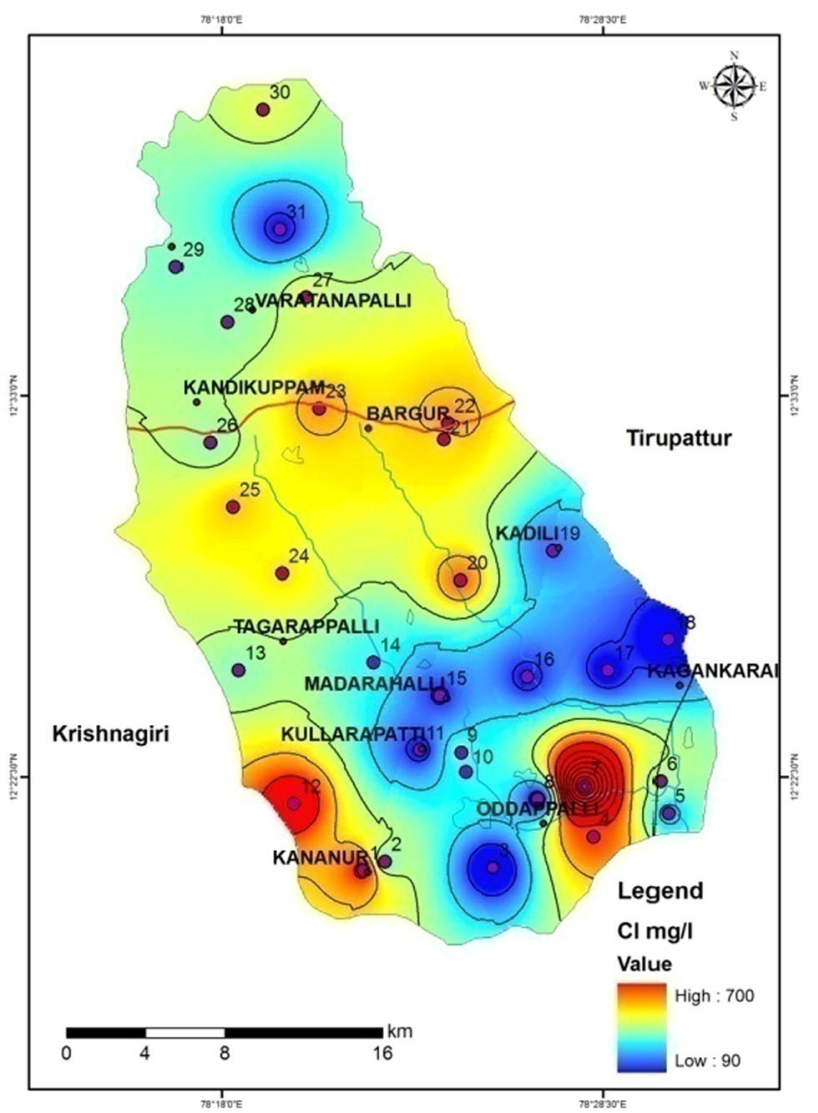

Fig. 11 Spatial variation of distribution of $\mathrm{Cl}$ in study area

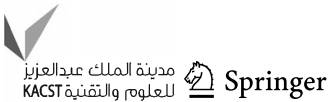


may be due to sewage infiltration or domestic effluents (Ranjana and Naverathna 2011).

\section{Cluster analysis}

This is a group of multivariate techniques which primarily classify (Massart and Kaufmann 1983) variables or cases (observation or samples) into the cluster with high homogeneity level within the class and high heterogeneity level between classes The spatial variability of groundwater was determined by the CA. CA was first performed to group all sample sites to classify them into a cluster to minimize their number. We use CA to link sample site in the configuration of a tree with different branches (Dendogram) which provide a visual summary of the clustering process, presenting a picture of the group and their proximity. Branches that have linkage closer to each other indicate a stronger relationship between sample/variables or cluster of sampling site/variable. In this present study, CA was applied for the grouping of parameters using the ward's linkage method (Ward 1963).

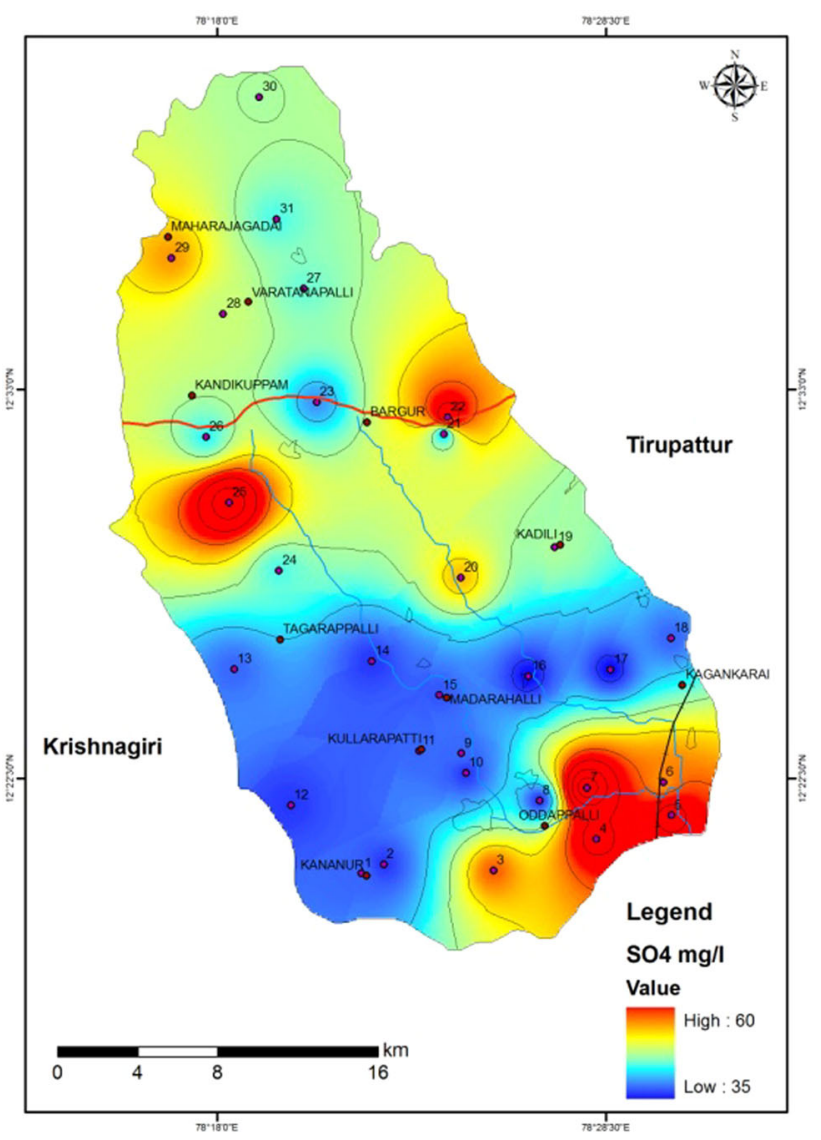

Fig. 12 Spatial variation of distribution of $\mathrm{SO}_{4}$ in study area
Cluster 1 comprised of EC and TDS showing close similarities which can be interpreted as natural mineralization and is controlled by cation exchange (Fig. 15). The cluster also indicates $\mathrm{Ca}-\mathrm{Mg}-\mathrm{Cl}$ facies, which resulted from the reverse cation exchange. The presence of TDS in this cluster is an indication that the cations and anions influence TDS and thus increases the water's electrical conductivity (EC). At high TDS concentration, water becomes saline (Shahbazi and Esmaeili-Sari 2009).

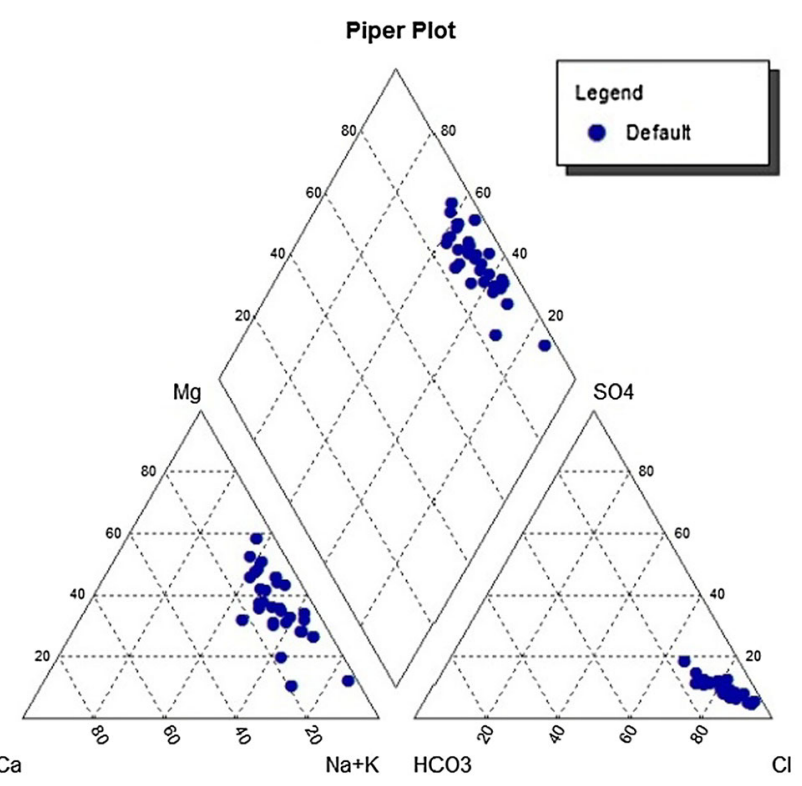

Fig. 13 Piper diagram

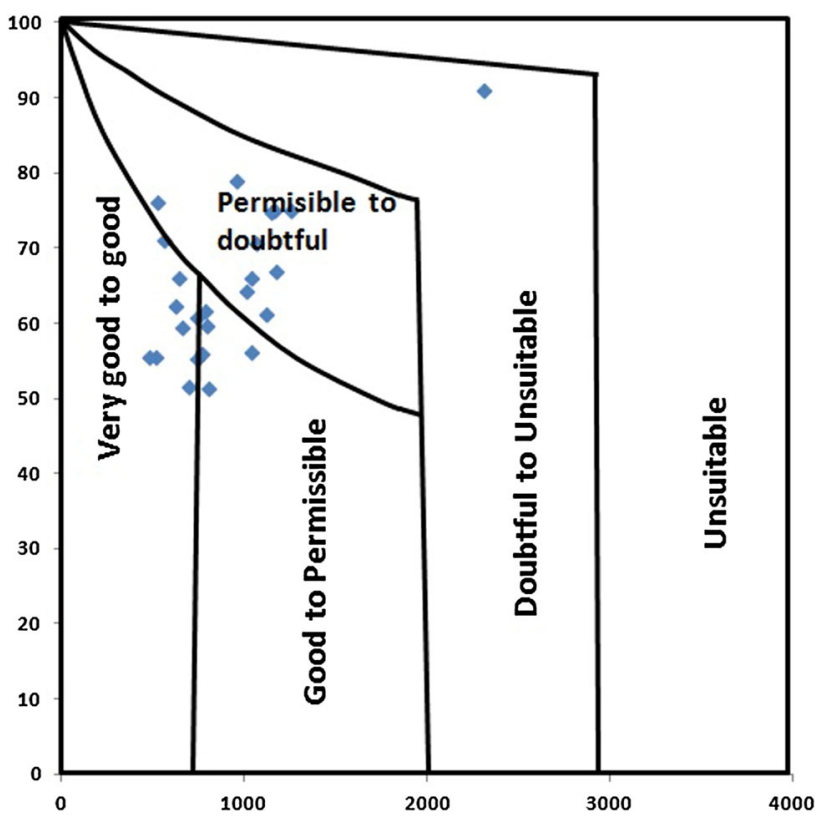

Fig. 14 Wilcox diagram 
Table 2 Correlation coefficient for groundwater quality parameters of Krishnagiri district and Vellore district

\begin{tabular}{|c|c|c|c|c|c|c|c|c|c|c|c|}
\hline & EC & $\mathrm{pH}$ & TDS & $\mathrm{Ca}$ & $\mathrm{Mg}$ & $\mathrm{Na}$ & K & $\mathrm{CO}_{3}$ & $\mathrm{HCO}_{3}$ & $\mathrm{Cl}$ & $\mathrm{SO}_{4}$ \\
\hline $\mathrm{EC}$ & 1.00 & & & & & & & & & & \\
\hline $\mathrm{pH}$ & 0.16 & 1.00 & & & & & & & & & \\
\hline TDS & 1.00 & 0.16 & 1.00 & & & & & & & & \\
\hline $\mathrm{Ca}$ & 0.11 & -0.38 & 0.11 & 1.00 & & & & & & & \\
\hline $\mathrm{Mg}$ & 0.24 & -0.07 & 0.24 & 0.07 & 1.00 & & & & & & \\
\hline $\mathrm{Na}$ & 0.97* & 0.20 & 0.97* & -0.05 & 0.09 & 1.00 & & & & & \\
\hline $\mathrm{K}$ & 0.18 & 0.04 & 0.18 & 0.08 & -0.01 & 0.04 & 1.00 & & & & \\
\hline $\mathrm{CO}_{3}$ & 0.12 & 0.75 & 0.12 & -0.31 & -0.12 & 0.17 & 0.03 & 1.00 & & & \\
\hline $\mathrm{HCO}_{3}$ & 0.22 & 0.00 & 0.22 & -0.08 & 0.16 & 0.26 & -0.24 & -0.04 & 1.00 & & \\
\hline $\mathrm{Cl}$ & 0.98* & 0.12 & 0.98* & 0.16 & 0.28 & $0.93 *$ & 0.17 & 0.06 & 0.10 & 1.00 & \\
\hline $\mathrm{SO}_{4}$ & 0.59 & 0.01 & $0.59 *$ & 0.05 & 0.02 & $0.60 *$ & 0.14 & 0.18 & 0.21 & 0.51 & 1.00 \\
\hline
\end{tabular}

* Correlation significant at 0.5 level

Fig. 15 Parameter wise analysis using cluster for groundwater quality of Krishnagiri and Vellore District

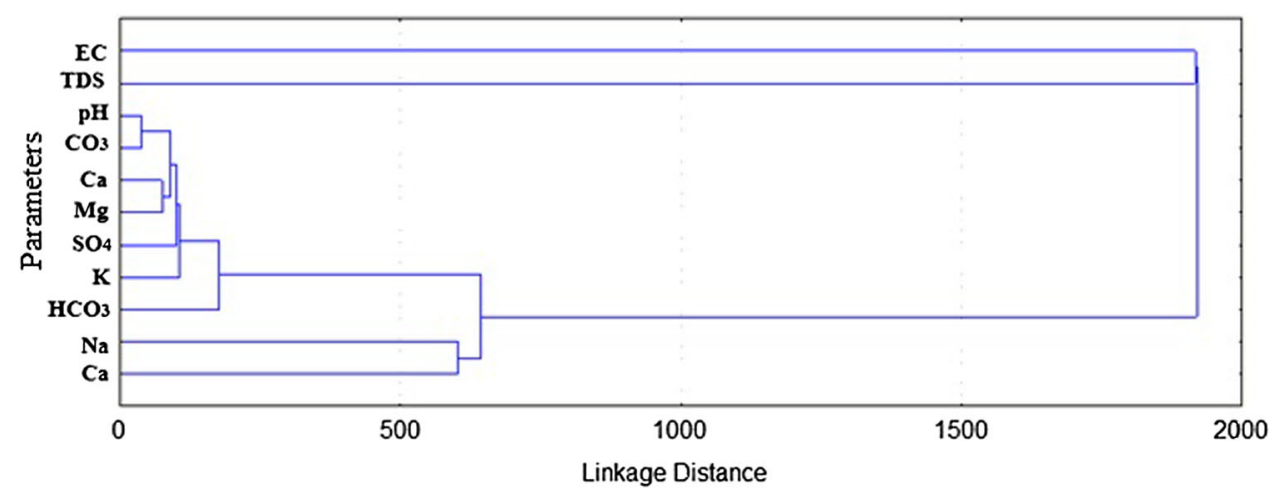

\section{Conclusion}

The cation chemistry of the groundwater shows excessive presence of $\mathrm{Na}$ except in few locations. The order of abundance is $\mathrm{Na}^{+}>\mathrm{Mg}^{2+}>\mathrm{Ca}^{2+}>\mathrm{K}^{+}$. The anion chemistry of the groundwater shows excessive presence of chloride except in few samples. The order of abundance is $\mathrm{Cl}^{-}>-$ $>\mathrm{SO}_{4}^{2-}>\mathrm{CO}_{3}^{2-}$. The result of hydrochemical facies reveals the type of water as $\mathrm{NaCl}$ with mixed $\mathrm{CaMgCl}$. In statistical analysis, the results show that the $\mathrm{Na}$ has significant correlation with $\mathrm{Cl}$ similarly correlated with $\mathrm{SO}_{4}$. Rock dissolution, Agriculture, domestic and other industrial effluence in the study area is responsible for the $\mathrm{Cl}$ and $\mathrm{Na}$ increase. Wilcox plot illustrates that $58 \%$ samples are suitable for irrigation. When comparing the analytical results with the World Health Organization's permissible limits and BIS standards that $40 \%$ of the sample is not potable water. The key source of all the hydrogeochemical process in the study area is due to lithology which is the parent control as well as anthropogenic influence such as effluents released from the nearby tanneries which govern the hydro geochemistry of the groundwater and make it unsuitable for drinking purpose. This inference will be much helpful for water resource managers to solve environmental problems in the society.

Open Access This article is distributed under the terms of the Creative Commons Attribution 4.0 International License (http:// creativecommons.org/licenses/by/4.0/), which permits unrestricted use, distribution, and reproduction in any medium, provided you give appropriate credit to the original author(s) and the source, provide a link to the Creative Commons license, and indicate if changes were made.

\section{References}

Annapoorna H, Janardhanab MR (2015) Assessment of groundwater quality for drinking purpose in rural areas surrounding a defunct copper mine. Aquatic Procedia 4:685-692. doi:10.1016/j.aqpro. 02.088

APHA (1999) Standard methods for the examination of water and wastewater, 20th edn. American Public Health Association, Washington DC

Arshid J, Aasimah T, Yousuf AR, Akbar M, Aabid HN (2011) Geochemistry and irrigation quality of groundwater along River Jhelum in South Kashmir, India. Recent Res Sci Technol 3(6):57-63 
Ashwani KT, Abhay KS (2014) Hydrogeochemical investigation and groundwater quality assessment of Pratapgarh District, Uttar Pradesh. J Geol Soc India 83:329-343

Bagyaraj M, Ramkumar T, Venkatramanan S, Gurugnanam B (2013) Application of remote sensing and GIS analysis for identifying groundwater potential zone in parts of Kodaikanal Taluk, South India. Front Earth Sci 7(1):65-75

BIS (2000) Drinking water specification. Bureau of Indian Standards, New Delhi

Central Ground Water Board (2009) Report. South Eastern Coastal Region, Chennai

Chandrasekar N, Selvakumar S, Srinivas Y, John Wilson JS, Simon Peter T, Magesh NS (2014) Hydrogeochemical assessment of groundwater quality along the coastal aquifers of southern Tamil Nadu, India. Environ Earth Sci 71:4739-4750

Dhiviyaa Pranavam TS, Venkatesa Rao T, Punithavathi L, Karunanithi S, Bhaskaran A (2011) Groundwater pollution in the Palar Riverbed near Vellore, Tamil Nadu, India. Indian J Sci Technol $4: 1$

Ewusi A, Obiri-yeboah S, Voigt HS (2013) Groundwater quality assessment for drinking and irrigation purposes in Obuasi Municipality of Ghana: a preliminary study. J Environ Earth Sci 5(1):6-17

Galy A, France-Lanord C (1999) Weathering process in the GangesBrahmaputra basin and the riverine alkalinity budget. Chem Geol 159:31-60

Gnanachandrasamy G, Ramkumar T, Venkatramanan S, Vasudevan S, Chung SY, Bagyaraj M (2013) Accessing groundwater quality in lower part of Nagapattinam district, Southern India: using hydrogeochemistry and GIS interpolation techniques. Appl Water Sci. doi:10.1007/s13201-014-0172-z

Ifatimehin OO, Musa SD (2008) The prospects of sustainable management of domestic 48 water supply and sanitation in Kogi strata. J Environ Policy Issues 4(1-2):33-44

Ishaku JM (2011) Assessment of groundwater quality index for Jimeta-Yola area, northeastern Nigeria. J Geol Mining Res 3(9):219-231

Kalpana L, Elango L (2013) Assessment of groundwater quality for drinking and irrigation purposes in Pambar river sub-basin, Tamil Nadu. Indian J Environ Protection 33(1):1-8

Krishna Kumar S, Logeshkumaran A, Magesh NS, Prince SG, Chandrasekar N (2014) Hydro-geochemistry and application of water quality index (WQI) for groundwater quality assessment, Anna Nagar, part of Chennai City, Tamil Nadu, India. Appl Water Sci. doi:10.1007/s13201-014-0196-4

Krishna Kumar S, Chandrasekar N, Seralathan P, Godson PS, Magesh NS (2011) Hydrogeochemical study of shallow carbonate aquifers, Rameswaram Island, India. Environ Monit Assess 184(7):4127-4139

Kumar SK, Rammohan V, Sahayam JD, Jeevanandam M (2008) Assessment of groundwater quality and hydrogeo-chemistry of Manimuktha River basin, Tamil Nadu, India. Environ Monit Assess. doi:10.1007/s10661-008-0633-7

Lee SM, Min KD, Woo NC, Kim YJ, Ahn CH (2003) Statistical models for the assessment of nitrate contamination in urban groundwater using GIS. Environ Geol 44:210-221

Massar DL, Kaufman L (1983) The interpretation of chemical data by the use of cluster analysis. Wiley, New York

Mitra BK, Sasaki K, Enari N, Matsuyama N, Fujita M (2007) Suitability assessment of shallow ground water for agriculture in sand dune area of northwest Honshu Island, Japan. Appl Ecol Environ Res 5(1):177-188

Nagarajan R, Rajmohan N, Mahendran U, Senthamilkumar S (2010) Evaluation of groundwater quality and its suitability for drinking and agriculture use in Thanjavur city, Tamil Nadu, India. Environ Monit Assess 171:289-308
Nagaraju A, Sunil Kumar K, Thejaswi A (2014) Assessment of groundwater quality for irrigation: a case study from Bandalamottu lead mining area, Guntur District, Andhra Pradesh, South India. Appl Water Sci 4:385-396. doi:10.1007/s13201-0140154-1

Padmalal D, Maya K, Narendra Babu K, Baiju RS, Babura B (2012) Hydro chemical characterization and water quality assessment of the coastal springs of southern Kerala, India. J Appl Geochem 14(4):466-481

Piper AM (1953) A graphic procedure in the chemical interpretation of water analysis, US Geological Survey Groundwater Note 12

Plummer LN, Bexfield LM, Anderholm SK (2003) How ground-water chemistry helps us understand the aquifer. In: Bartolino JR, Cole JC (eds) U.S. Geological Survey Circular, p 1222

Public Work Department Report (2004)

Rajmohan N, Elango L, Ramachandran S, Natarajan M (2000) Major ion correlation in groundwater of Kancheepuram region, south India. Indian J Environ Protection 20(3):188-193

Raju NJ, Shukla UK, Ram P (2011) Hydrogeochemistry for the assessment of groundwater quality in Varanasi: a fast-urbanizing center in Uttar Pradesh, India. Environ Monit Assess 173:279-300

Ranjana UK, Naverathna MPC (2011) River sand mining in southern Sri-Lanka and its effect on environment. In: 11th International River symposium on "A Future of extremes" Brisbane, Australia

Ravisankar N, Poongothai S (2008) A study of groundwater quality in Tsunami affected areas of Sirkazhi taluk, Nagapattinam district, Tamil Nadu, India. Sci Tsunami Hazards 27(1):47-55

Sajil Kumar PJ, Elango L, James EJ (2013) Assessment of hydrochemistry and groundwater quality in the coastal area of South Chennai, India. Arab J Geosci. doi:10.1007/s12517-0130940-3

Sarath Prasanth SV, Magesh NS, Jitheshlal KV, Chandrasekar N (2012) Evaluation of groundwater quality and its suitability for drinking and agricultural use in the coastal stretch of Alappuzha District, Kerala, India. Appl Water Sci 2(3):165-175

Selvam S, Manimaran G, Sivasubramanian P (2013) Hydrochemical characteristics and GIS-based assessment of groundwater quality in the coastal aquifers of Tuticorin corporation, Tamil Nadu, India. Appl Water Sci 3:145-159

Shahbazi A, Esmaeili-Sari A (2009) Groundwater quality assessment in North of Iran: a case study of the Mazandaran Province. World Appl Sci J 5:92-97

SinghA K, Hasnain SI (1998) Major ion chemistry and weathering control in a high altitude basin: Alaknanda river, Garhwal Himalaya, India. Hydrol Sci 43(6):825-843

Srinivas Y, Hudson Oliver D, Stanley Raj A, Chandrasekar N (2013) Evaluation of groundwater quality in and around Nagercoil town, Tamil Nadu, India: an integrated geochemical and GIS approach. Appl Water Sci 3:631-651

Srinivasamoorthy K, Chidambaram S, Prasanna MV, Vasanthaviha M, Peter John, Anandhan P (2008) Identification of major sources controlling groundwater chemistry from a hard rock terrain: a case study from Mettur taluk, Salem district, Tamil Nadu, India. J Earth Syst Sci 117(1):49-58

Srinivasamoorthy K, Nanthakumar C, Vasanthavigar M, Vijayaraghavan K, Rajivgandhi R, Chidambaram S, Anandhan P, Manivannan R, Vasudevan S (2011) Groundwater quality assessment from a hard rock terrain, Salem District of Tamil Nadu, India. Arab J Geosci 4:91-102

Subramanian A (2011) Ground water quality assessment of Nagercoil Town (Hand pumps). J Environ Earth Sci 1(1):1-5

Tiwari KK, Prasad RN, Ram Chandra, Mondal NC (2012) Geochemical parameters for assessment of groundwater quality around urban and suburban areas of Dausa city in Rajasthan, India. J Appl Geochem 14(2):184-193 
Toth J (1999) Groundwater as a geologic agent: an overview of the causes, processes and manifestations. Hydrogeol J 7:1-14

UNESCO (2000) Groundwater pollution. International Hydrological Programme
Ward JH Jr (1963) Hierarchical grouping to optimize an objective function. J Am Stat Assoc 58:236-244

WHO (2004) WHO Guidelines for Drinking-water Quality 4th edn. World Health Organization 